\title{
Isolation and Characterisation of Fusarium Resistance Gene Candidates in Zingiber spp. of North East India
}

\author{
N.C. Lenbi ${ }^{1,2}$, Huidrom Sunitibala Devi ${ }^{1 *}$ and Pratap Jyoti Handique ${ }^{2}$ \\ ${ }^{1}$ Institute of Bioresources and Sustainable Development (IBSD), Imphal, Manipur, India \\ ${ }^{2}$ Department of Biotechnology, Gauhati University, Assam, India \\ *Corresponding author
}

\section{A B S T R A C T}

\begin{tabular}{|l|}
\hline K e y w o r d s \\
$\begin{array}{l}\text { R-genes, Resistance gene } \\
\text { candidates (RGC), CC- } \\
\text { NBS-LRR class, } \\
\text { Fusarium oxysporum f. } \\
\text { sp. Zingiberi }\end{array}$ \\
\hline Article Info \\
\hline $\begin{array}{l}\text { Accepted: } \\
\text { 06 August } 2018 \\
\text { Available Online: } \\
\text { 10 September } 2018\end{array}$ \\
\hline
\end{tabular}

Rhizome rot and yellows caused by Fusarium oxysporum f. sp. Zingiberi, is a serious a serious soil-borne disease of ginger and found to be prevalent in the north-east region of India. Most of the plant disease resistance (R) genes encode a highly conserved nucleotide binding site and leucine-rich repeat structure (NBS-LRR). These structure can be used to isolate candidate genes for Fusarium resistance in Zingiber spp. Degenerate oligonucleotides which have been designed to recognize conserved coding regions of known resistance $(\mathrm{R})$ genes from different species of plant in literature were obtained to target PCR to amplify resistance gene analogs (RGAs) from Zingiber spp. of north east India. PCR amplification from genomic DNA yielded a group of fragments of approximately $350 \mathrm{bp}$ and $600 \mathrm{bp}$ DNA sequences. From the results we can conclude that Zingiber RGCs belong to the CC-NBS-LRR class of proteins and no TIR-RGCs were found in the study. Although RGCs were detected with degenerate RGC primers and the RGC-specific primers we designed. The expression of the disease resistance seems to be very low or absent in the Zingiber species found in the region.

\section{Introduction}

Ginger (Zingiber officinale Rosc., family Zingiberaceae $2 \mathrm{n}=22$ ), is an important commercial crop in tropical and subtropical countries. Ginger is asexually propagated from portions of the rhizome.

Globally India is the largest producer and exporter of the finest quality ginger. It is estimated that more than $50 \%$ of the national production ginger comes from the North Eastern States. Ginger is used throughout the world as a spice or fresh herb or in medicines.
Cultivated ginger originated in India or Southeast Asia (Ravindran et al., 1994). Globally, the main producers of ginger are India, China, Nepal, Indonesia and Nigeria (FAOSTAT 2010). India is the largest producer and exporter of the finest quality ginger. India's production of ginger constitutes about $34.6 \%$ of the total world's production of ginger (FAOSTAT data, 2014). Ginger is grown in almost all the states of the North-Eastern region of India. Assam ranks first in ginger acreage as well as in production but productivity was highest in Mizoram, followed by Arunachal Pradesh, Assam and 
Nagaland (H Rahman et al., 2009). A number of local cultivars of ginger are also found in North-Eastern region. These varieties are high yielder of rhizomes as compared to standard cultivars like Nadia and Rio-De-Janeiro but have more fibre content.

Ginger is one of the most promising spice crop grown in North eastern India. It is estimated that more than $50 \%$ of the national production of ginger comes from the North Eastern States. The soil, climate and other ecological factors of the region enormously favours the growth and development of the crop and there is a tremendous scope to develop for increase in its yield per unit area. As such the farmers here are interested for the cultivation of the crop. But it seems the continuous domestication of preferred genotypes of ginger and their exclusive vegetative propagation have resulted in the degradation of the genetic base of this crop and due to this almost all the cultivars available today are equally susceptible to all major diseases.

In India, rhizome rot and yellows caused by Fusarium oxysporum f. sp. Zingiberi (fusarium yellows on ginger) is a big threat to the production of this crop (Stirling, 2004). Rhizome rot is found to be prevalent in many areas of north-east India as well. As ginger is an obligatory asexual crop, resistance breeding is limited only to its germplasm screening (Ravindran et al., 2005). Till now no work has been taken upto evaluate the wild relatives of ginger for Fusarium wilt resistance in North east India. Therefore, the genetic resources of ginger needs to be accessed for identification of Fusarium resistance. As such, the most sought after techniques of genetic improvement for disease management, could be applied to increase the yields of the crop in the region. Resistance gene candidates (RGCs) hold much promise to investigate features of resistance-related loci in ginger for its genetic improvement.
Plant disease resistance genes (R-genes) are found to be an important component of the genetic resistance mechanism in plants (Flor 1971; Dangl and Jones 2001). R-genes have a key role in recognizing proteins expressed by specific a virulence (Avr) genes of pathogens (Flor 1956). The NBS-LRR $R$-genes seems to be abundant in plant genomes with approximately 150 and 600 isolated from Arabidopsis and rice respectively (Meyers et al., 2003; Zhou et al., 2004).

About $75 \%$ of plant $R$-genes encode proteins with a nucleotide-binding site and leucine-rich repeat (NBS-LRR) domains that conferring resistance to various pest and pathogens such as bacteria, fungi, viruses, insects and nematodes (Dangl and Jones, 2001). The Cterminal LRR acts as a site for pathogen recognition and the N-terminal NBS initiate signaling which activates signal transduction pathways leading to disease resistance in the plant (Belkhadir et al., 2004).

Wild relatives of many other plants have been used as an important source of genetic variation for disease resistance (Xiao et al., 1998; Zamir, 2001) since they can evolve resistance specificities more efficiently than cultigen (Clay and Kover, 1996; Ebert and Hamilton, 1996). In this context molecular characterization of resistance-related sequences from ginger and its wild relatives may provide a lead towards retrieving resistance specificities suitable for the improvement of ginger.

\section{Materials and Methods}

\section{Plant Materials collected}

Species of genus Zingiber, Z. montanum, Z. zerumbet var. darcyi, Z. officinale Roscoe var. Nadia, Z. officinale Roscoe var. Baishy, $Z$. officinale Roscoe var. Meitei shing, $Z$. zerumbet (L.) Smith, Z. kerrii Craib, Z. rubens 
Roxb, Z. sp3, Z. sp1, Z.sp2 were obtained from Bioresource Park, Institute of Bioresources and Sustainable Development (IBSD), Hararou, Manipur where the cultivars are maintained as accessions under shade house conditions.

Apart from these, Zingiber spp. spreading across different locations of north east from farmer's fields were collected and maintained as accessions in greenhouse which include, $Z$. purpureum, $Z$. roseum, $Z$. zerumbet (L.) Smith, different cultivars of $Z$. officinale, $Z$. montanum and Meitei shing.

\section{Isolation of genomic DNA}

Total genomic DNA was extracted from young leaves using CTAB method using the procedure of Doyle and Doyle (1987) with minor modifications. DNA was diluted to 20 $\mathrm{ng} / \mu \mathrm{l}$ final concentration in sterile deionised water and stored in $1 \mathrm{X}$ TE buff er $(10 \mathrm{mM}$ Tris $\mathrm{HCl} \mathrm{pH} 8,1 \mathrm{mM}$ EDTA pH 8) at $-20{ }^{\circ} \mathrm{C}$. The quantity and quality of DNA preparation were verified by standard spectrophotometry methods (Nanodrop Spectrophotometer ND 2000) and visualized on $0.8 \%$ agarose gel stained with ethidium bromide.

\section{Primers and PCR amplification}

A Total of 10Resistance gene specific degenerate primers (Table 1, Sigma Aldrich Chemicals Pvt. Ltd., India) previously used in published literature for amplifying RGCs in other crops were selected. PCR reaction was carried out in a volume of $25 \mu$ l containing 1 unit Taq DNA polymerase, 10X PCR buffer, $1.5 \mathrm{mM}$ of $\mathrm{MgCl} 2,200 \mathrm{mM}$ of dNTPs, 20 picomole of each primer and $30 \mathrm{ng}$ of template DNA,. PCR amplification was carried out in a thermal cycler Eppendorf Master cycler pro $S$ programmed for an initial denaturation at $94^{\circ} \mathrm{C}$ for $5 \mathrm{~min}$, followed by 35 amplification cycles, $94^{\circ} \mathrm{C}$ for $1 \mathrm{~min}, 55^{\circ} \mathrm{C}$ for $1 \mathrm{~min}$ and $72^{\circ} \mathrm{C}$ for $1 \mathrm{~min}$ and a final extension step at $72^{\circ} \mathrm{C}$ for $5 \mathrm{~min}$.

\section{Sequencing and phylogenetic analysis}

The PCR amplification products were cloned and sequenced at Bioserve Biotechnologies (INDIA) Pvt. Ltd., Hyderabad. The sequence data were subjected to GenBank searches with BLAST (Altschul et al., 1990) and BLASTN algorithm via the National Centre for Biotechnology Information (NCBI) web site. Multiple alignment of the nucleotide and amino acid sequences were performed using Clustal Omega program of EMBL-EBI. Phylogenetic analyses were performed using MEGA6 software and a Neighbor joining tree based on DNA sequence CLUSTALW alignment of the resistance gene candidates were constructed. Robustness of clustering was checked by bootstrapping 1000 replicates. ORF Finder was used to find the ORF in the DNA sequence (www.ncbi.nlm.nih.gov/ orffinder/) (Table 2).

\section{RNA isolation and RT-PCR analysis}

Zingiber RGC-specific primer pairs were deduced from the RGCs isolated from the amplified Zingiber spp. using the software Primer-Blast in NCBI. Altogether 10 RGCspecific primers were designed. Using these primers, conditions for PCR amplification were standardized using genomic DNA. Total RNA was isolated from young leaves collected from infected fields using RNA isolation kit (RN easy Mini Kit, QIAGEN). Total RNA was treated with DNase I to remove any traces of genomic DNA. The RNA was treated with DNase I (Promega, USA) for $1 \mathrm{~h}$ to remove DNA contamination. The RT-PCR reactions were performed using One Step RT PCR kit (Invitrogen) following the instructions. The reaction included a positive control with Actin specific primers and a negative control without RNA. The 
reaction conditions were $5 \mathrm{~min}$ at $94^{\circ} \mathrm{C}$, followed by 35 cycles of denaturing at $94^{\circ} \mathrm{C}$ for $1 \mathrm{~min}$, annealing at $55-57^{\circ} \mathrm{C}$ for $30 \mathrm{sec}$, and elongating at $72^{\circ} \mathrm{C}$ for $2 \mathrm{~min}$ followed by a final extension at $72^{\circ} \mathrm{C}$ for $7 \mathrm{~min}$. Amplicons were separated on a $1.2 \%$ agarose gel.

\section{Results and Discussion}

\section{Amplification of RGCs from Zingiber spp.}

Using the 10 resistance gene specific degenerate primers, PCR products were obtained from genomic DNA templates of Zingiber spp. The amplification products were visualized following electrophoresis in 1.8\% agarose gel (Sigma Aldrich Chemicals Pvt. Ltd., India) in 0.5X TBE (10X stock contained $1 \mathrm{M}$ Tris, $0.8 \mathrm{M}$ boric acid, 0.5 M EDTA), and staining with ethidium bromide $(0.5 \mathrm{mg}=\mathrm{ml})$. The gels were photographed under a gel documentation system (Perkin Elmer Geliance 200). PCR amplification resulted in the production of major band in the expected size range of $\sim 600 \mathrm{bp}$ and $\sim 350 \mathrm{bp}$ as reported in the literature for other plant species after amplification at $55^{\circ} \mathrm{C}$ annealing temperature (Fig. 1 and 2).

\section{Sequence characterisation and phylogenetic relationships of Zingiber RGCs}

The 16 selected sequence data were subjected to GenBank searches with BLAST (Altschul et al., 1990) and BLASTN algorithm via the National Centre for Biotechnology Information (NCBI) website. No significant similarity was found in $4 \mathrm{RGC}$ sequence data with the databases in the GenBank. The amplification of such unrelated sequences may be due to the amplification on basis of P-loop alone (Rigden et al., 2000). Remaining RGC sequences showed a high level of sequence identity to comparable regions of disease resistance genes in GenBank, supported by low e-values (Table 3). The level of sequence identity between Zingiber RGC sequences and known resistance genes in the top blast hits varied from $87 \%$ to $91 \%$ between Zne19p6 and Zne31p6 respectively to Zingiber officinale clone ZoP26 (e-value: 1e-106) and Zingiber zerumbet clone ZzP226 (e-value: 1e81). BLASTP analysis in the genebank database of deduced amino acid sequences revealed detection of putative conserved domains of super families NS-ARC, significant homology to well characterised Rgenes from other plant species and similarity to putative disease resistance proteins. The presence of NB-ARC domain shows the amino acid sequences to be analogous to plant $\mathrm{R}$-gene products. Out of the 16 deduced amino acid sequences 7 sequences were unrelated to resistance genes. Further analysis of the sequences using ORF Finder at NCBI server revealed that all the16 sequences could be translated into a single open reading frame (ORF) of length ranging from 100 amino acids to 138 amino acids. Further analysis of these 16 RGCs revealed the presence of stop codons in 13 out of the 16 Zingiber RGCs.

Multiple alignment of the nucleotide sequences and deduced amino acid sequences were performed using Clustal Omega program of EMBL-EBI (Fig. 3). The amino acid alignment showed homology of Zingiber RGCs with targeted NBS-LRR domains of well characterized $\mathrm{R}$ genes from other plants. NBS-LRR domain is found to be the largest class of plant R-genes. Around 150 genes in the genome of Arabidosis thaliana are reported to code for NBS-LRR motifs (Meyers et al., 2003). Such a wide prevalence of the NBSLRR gene signifies their ancient origin (Dangl and Jones, 2001). Moreover, several features of the RGC sequences isolated shows that RGC sequences belong to non-TIR NBS-LRR class of resistance gene. In this study also no TIR type sequences were found as have been reported from earlier similar works (Meyers $e t$ al., 1999: Pan et al., 2000: Cannon et al., 
2002: Joshi et al., 2012). It seems in the earlier studies, TIR domain have not been reported in the NBS-LRR R-genes of other monocots such as in wheat (Dilbirligi and Gill, 2003), rice (Monosi et al., 2004; Zhou et al., 2004) and maize (Xiao et al., 2006).

Phylogenetic analyses were performed usingMEGA7 software and a Neighbor joining tree based on amino acid CLUSTALW alignment of the resistance gene candidates were constructed (Fig. 4). It was carried out to examine the relationships of Zingiber resistance gene candidates (RGCs) among themselves and to R-genes from other plant species. Robustness of clustering was checked by boot strapping 1,000 replicates and bootstrap values are given at the branch points. The data revealed moderate to high diversity in the collection, clustering them into four major phylogenetic groups (A-D). The
Zingiber RGCs consists of non TIR NBS-LRR disease resistance proteins. Group A consist of 9 RGCs, group B consist of 7 RGCs, group C and $\mathrm{D}$ consist of $3 \mathrm{RGC}$ sequences each. In group A sequences of CC NBS LRR of NBS LRR class were clustered together. Further, all the groups i.e., A-D is clustered into two subcluster each.

Group B comprises RGC sequences where no putative conserved domains have been detected. The sequences identified in group A can be treated as resistance gene candidates (RGCs) based on their high level of sequence identities to known R-genes from other species, considerably long open reading frames and presence of conserved motifs characteristic of NBS-LRR $\mathrm{R}$ genes. The phylogenetic result shows that Zingiber RGCs mainly comprised of CC-NBS-LRR class of disease resistance gene.

Table.1 List of RGC specific degenerate primers used for the PCR amplification of Zingiber resistance gene candidate

\begin{tabular}{|c|c|c|c|}
\hline \multirow[t]{2}{*}{ Primer } & \multicolumn{2}{|c|}{ Sequence $\left(5^{\prime} \rightarrow 3^{\prime}\right)$} & \multirow[t]{2}{*}{ Targeted domain } \\
\hline & Forward & Reverse & \\
\hline FR1 & $\begin{array}{l}\text { TGGTGG GGTTGGGAA } \\
\text { GACAACG }\end{array}$ & TCCCGCTAGTGGCAA TCCCTAG & $\begin{array}{l}\text { NBS-LRR/P-loop: } \\
\text { NBS-LRR }\end{array}$ \\
\hline FR2 & GGIGGIGTIGGIAAIACIAC & A(A/G)IGCTA(A/G)IGGIA(A/G)ICC & P-loop; GLPL \\
\hline FR4 & GGTGGGGTTGGGAAGACAACG & CACGCTAGTGGCAATCC & P-loop; GLPL \\
\hline FR5 & CCGGGITCAGGIAARACWAC & $\begin{array}{l}\text { CCCGAAGGAAACCRISRACWAR } \\
\text { A }\end{array}$ & $\begin{array}{l}\text { P-loop /hydrophobic } \\
\text { domain }\end{array}$ \\
\hline FR6 & GGIGGIGTIGGIAA(A/G)ACIAC & A(A/G)IGCIA(A/G)IGGIA(A/G)ICC & NBS-LRR/P-loop \\
\hline FR16 & $\begin{array}{l}\text { GGWATGGGWGGWRTHGGWA } \\
\text { ARACHAC }\end{array}$ & $\begin{array}{l}\text { ARNWYYTTVARDGCVARWGGV } \\
\text { ARWCC }\end{array}$ & \\
\hline FR19 & GGNGGNRTNGGNAARACCAC & CAANGCCAANGGCAANCC & $\begin{array}{l}\text { P-loop /hydrophobic } \\
\text { domain }\end{array}$ \\
\hline FR20 & GGTGGGGTTGGGAAGACAACG & CAACGCTAGTGGCAATCC & $\begin{array}{l}\text { NBS-LRR/P-loop: } \\
\text { NBS-LRR }\end{array}$ \\
\hline FR21 & GGNGTNGGNAARACNAC & ARIGCTARIGGIARICC & $\begin{array}{l}\text { P-loop; } \\
\text { GLPL9S/A)L }\end{array}$ \\
\hline FR 23 & GGIGGIGTIGGIAAIACIAC & ARIGCTARIGGIARICC & $\begin{array}{l}\text { NBS-LRR/P-loop; } \\
\text { NBS-LRR }\end{array}$ \\
\hline
\end{tabular}


Table.2 List of RGC specific primers designed using NCBI Primer Blast software

\begin{tabular}{l|l|l|l|}
$\begin{array}{l}\text { SI } \\
\text { no. }\end{array}$ & Primer & \multicolumn{2}{|c}{ Sequence $\left(\mathbf{5}^{\prime} \rightarrow \mathbf{3}^{\prime}\right)$} \\
\cline { 3 - 5 } & & \multicolumn{1}{|c}{ Forward } & \multicolumn{1}{c}{ Reverse } \\
\hline $\mathbf{1}$ & RSP1 & AGTCATGGTGTTCACGACCC & CTGAGGGGAGAAGATCCCCA \\
\hline $\mathbf{2}$ & RSP2 & ACCACTGCAGGACAGTGATG & GCTTCTGGCCTTGCTCAGTA \\
\hline $\mathbf{3}$ & RSP3 & AGGCTGACATGAAAGGGCTC & GAGGCGTGCGCATTCTTTAG \\
\hline $\mathbf{4}$ & RSP4 & GCAGGCAAAAGAAAGGCTCC & GGCCTGCCATTTTCAGCAA \\
\hline $\mathbf{5}$ & RSP5 & GAGAGGAGTGGTGTTGGGTG & TCCCCATCGTTGTTCTGCTC \\
\hline $\mathbf{6}$ & RSP6 & CCAGCATTCGAGGGGAGAAC & GGATGGCACACTCGGCTATT \\
\hline $\mathbf{7}$ & RSP7 & GCAGTGTGTGCAGTCCTAGA & CGTGTCATTTGGGTTGTGC \\
\hline $\mathbf{8}$ & RSP8 & CAGCCCCTTAAAGTCGTGGT & ACATCCCCATCGTGGTTCTG \\
\hline $\mathbf{9}$ & RSP9 & GGATGGCACACTCGGCTATT & ATCACACGATGTCTCGCTGG \\
\hline $\mathbf{1}$ & RSP10 & TGGAGCAGTCTTTTGGTGGC & CCTGCAGTGTGTTCAGTCCT \\
\hline
\end{tabular}

Table.3 Similarity of Zingiber RGC to accessions within GenBank using BLASTN

\begin{tabular}{|l|l|l|l|l|}
\hline $\begin{array}{l}\text { SI } \\
\text { no. }\end{array}$ & RGC & \multicolumn{1}{|c|}{ Blast top hits, organism, Description } & Identities & e-value \\
\hline 1 & zne10p6 & $\begin{array}{l}\text { Zingiber officinale cloneZoP26 CC-NBS-LRR } \\
\text { disease resistance protein-like gene, partial } \\
\text { sequence }\end{array}$ & $89 \%$ & $3 \mathrm{e}-124$ \\
\hline $\mathbf{2}$ & zne19p6 & $\begin{array}{l}\text { Zingiber officinale cloneZoP26 CC-NBS-LRR } \\
\text { disease resistance protein-like gene, partial } \\
\text { sequence }\end{array}$ & $87 \%$ & $1 \mathrm{e}-106$ \\
\hline $\mathbf{3}$ & zne30p6 & $\begin{array}{l}\text { Zingiber zerumbet cloneZzP29 CC-NBS-LRR } \\
\text { disease resistance protein-like gene, partial } \\
\text { sequence }\end{array}$ & $90 \%$ & $1 \mathrm{e}-77$ \\
\hline $\mathbf{4}$ & zne31p6 & $\begin{array}{l}\text { Zingiber zerumbet cloneZzP226 CC-NBS-LRR } \\
\text { disease resistance protein-like gene, partial } \\
\text { sequence }\end{array}$ & $91 \%$ & $1 \mathrm{e}-81$ \\
\hline $\mathbf{5}$ & zne23p6 & $\begin{array}{l}\text { Zingiber zerumbet cloneZzP226 CC-NBS-LRR } \\
\text { disease resistance protein-like gene, partial } \\
\text { sequence }\end{array}$ & $89 \%$ & 2e-150 \\
\hline 6 & zne24p6 & $\begin{array}{l}\text { Zingiber zerumbet putative CC-NBS-LRR disease } \\
\text { resistance protein gene, partial sequence }\end{array}$ & $91 \%$ & $1 \mathrm{e}-156$ \\
\hline
\end{tabular}


Fig.1 PCR amplification products of 350bp generated by the RGC specific degenerate primer pairs FR19 in different cultivars of Zingiber spp. lane M- 100bp ladder; lane1-Z. officinale var.

Meitei shing; lane 2- Z. zerumbet; lane 3-Z. Roseum; lane 4- Z. officinale bht; lane 7- Z. officinale bpt; lane 9-Z. sp 74; lane 10-Z. sp 101, lane11-Z. zerumbet 126; lane 12- Z cassumnar 12; lane 13- Z. zerumbet 42; lane 14- Z. zerumbet var. Darceyi Lane15- T3 Z. montanum; lane 16- T6 Z. montanum; lane 17- Z. officinale ms; lane 18- T5 Z. officinale

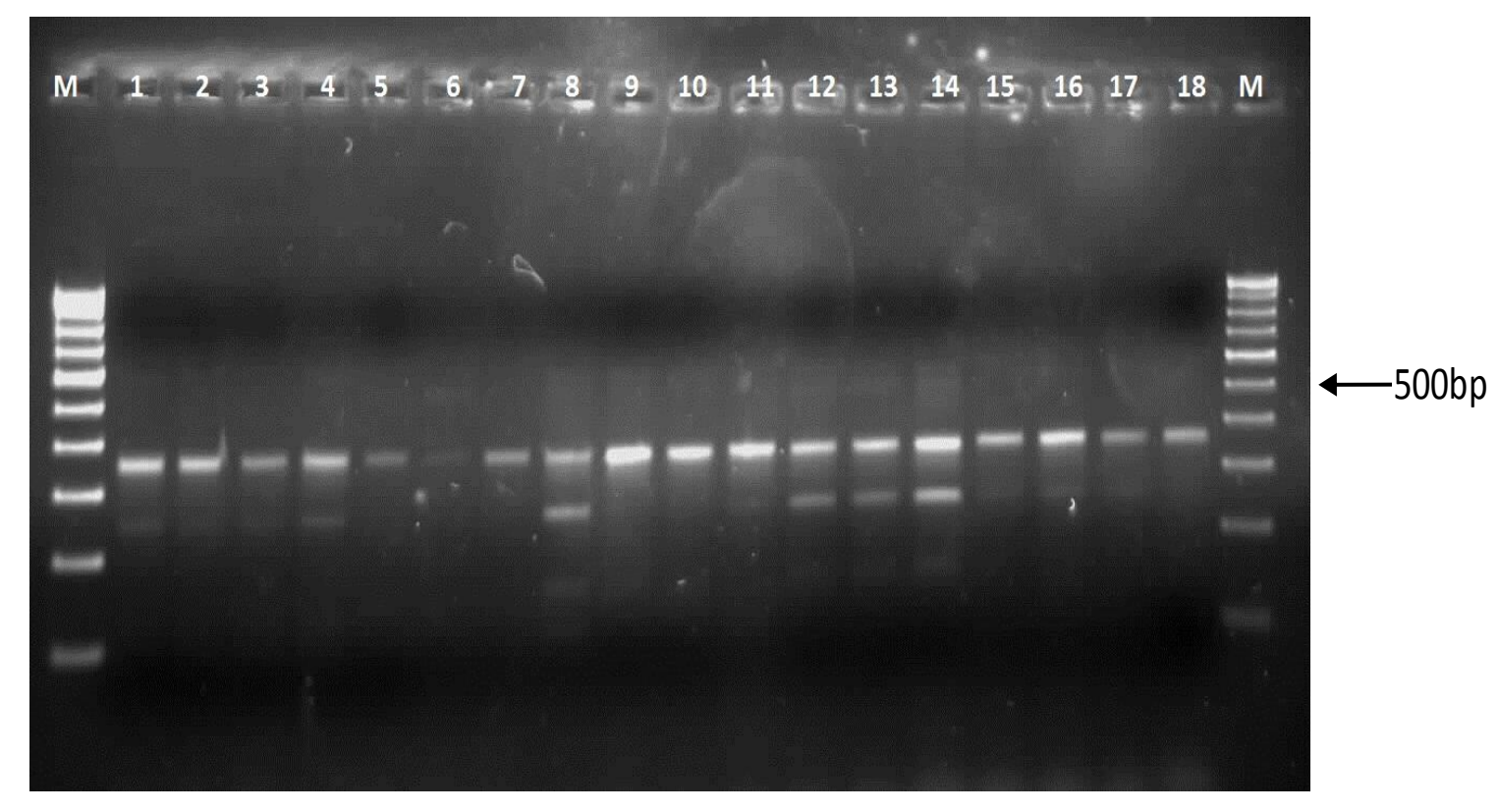

Fig.2 PCR amplification products of 600bp generated by the RGC specific degenerate primer pairs FR6 in different Zingiber spp. lane M- 100bp ladder; ; lane 1- Z. zerumbet; lane 2- Z. zp 101; lane4- Z. zerumbet var. Darceyi; lane7- Z. cassumnar 12

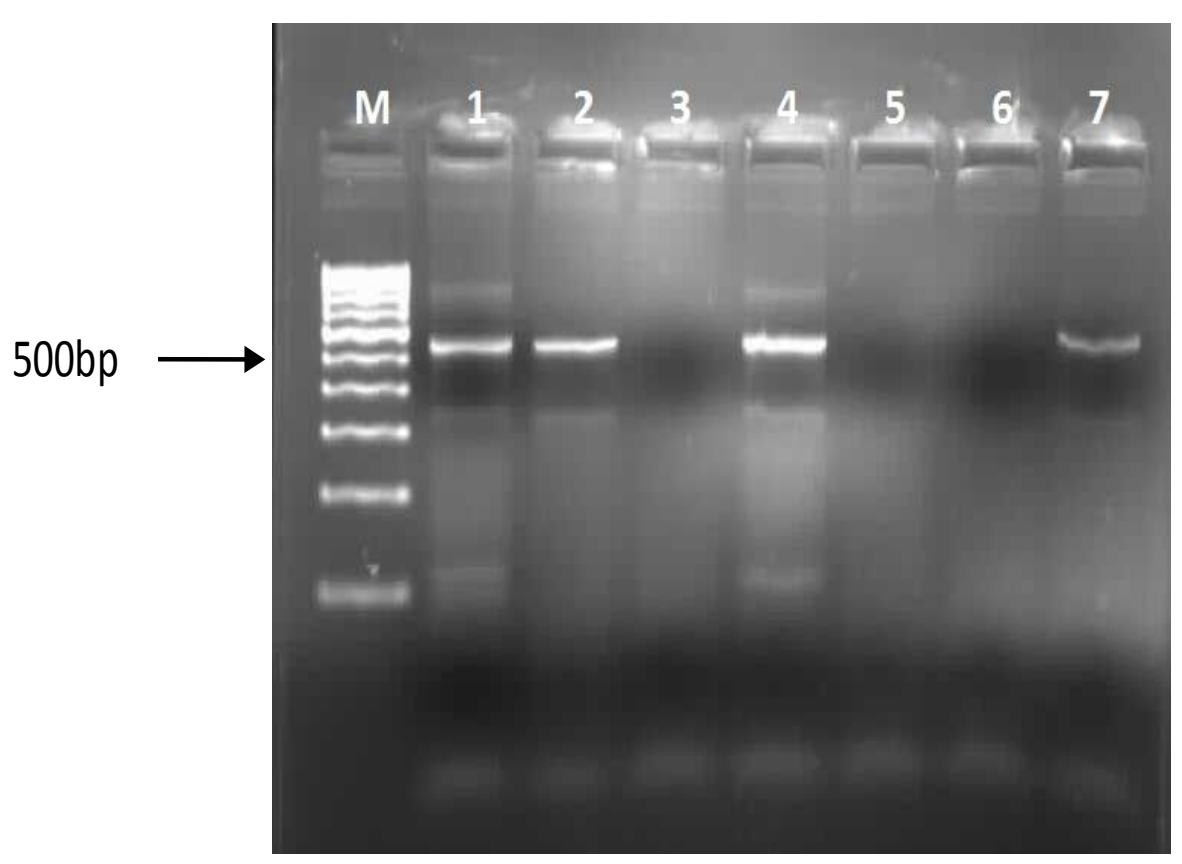


Fig.3 Multiple amino acid sequence alignment of representative Zingiber RGCs with NBS domains of R-genes using the CLUSTAL Omega program of EMBL-EBI

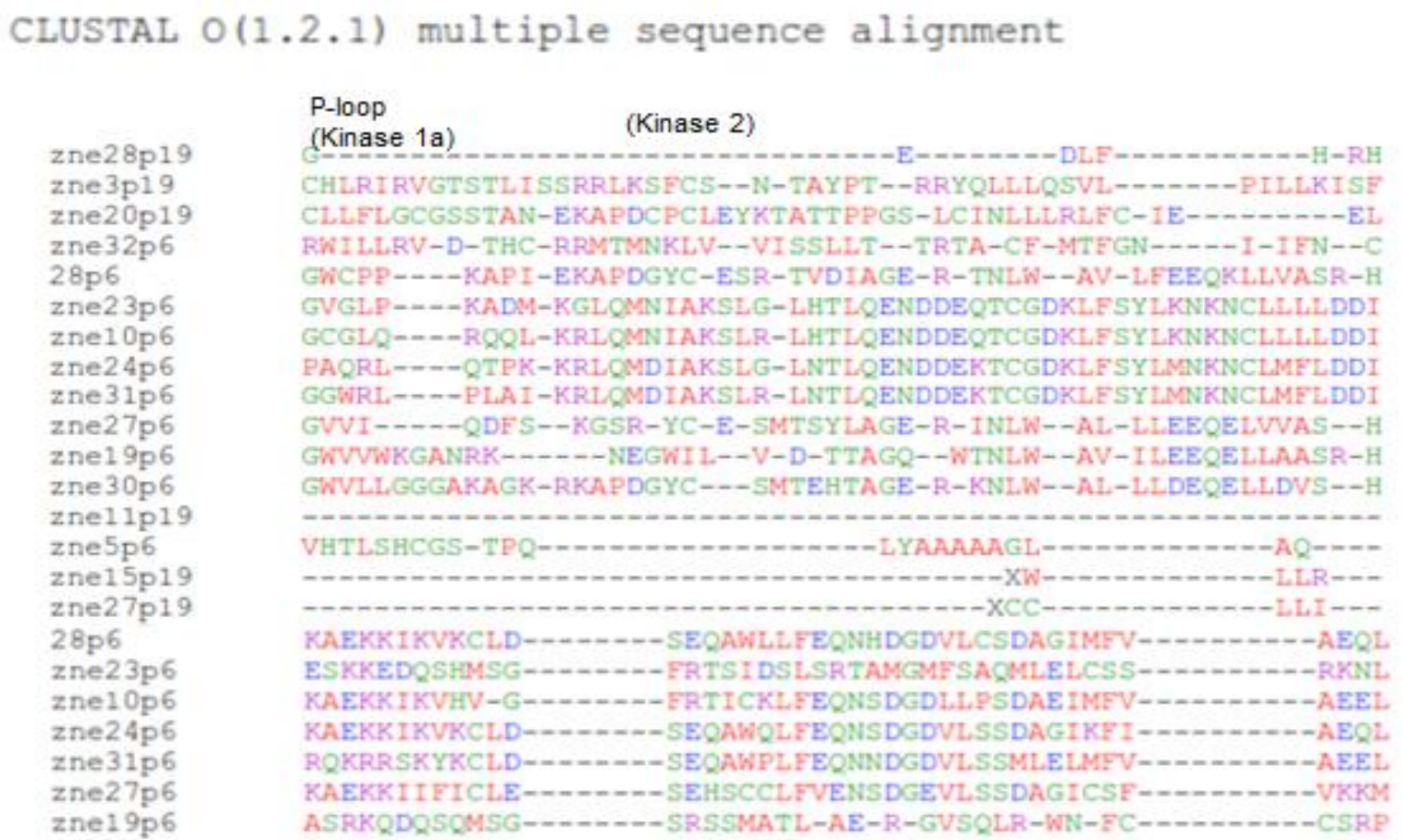

RNBS-A non-TIR

zne24p6

zne31p 6

zne27p6

zne19p6

zne30p6

zne11p19

zne $5 \mathrm{p} 6$

zne15p19

zne27p19

zne28p19

zne 3 p 19

zne20p19

zne32p6

$28 \mathrm{p} 6$

zne23p6

zne10p6

zne24p6

zne31p6

zne27p6

zne19p6

zne30p6

zne11p19

zne 5 p 6

zne15p19

zne27p19

\begin{abstract}
WEHLNLQLLGMAHSATEQG---QQ---QQ-----------PRKVVVFTTRSETVCAQM WEHLNLQLLGMAHSATEQG---QQ---QQ------------PRKVVVFTTRSETVCAQL-------GASESSTVGD--GTLGY-TRPPA-----VS-APPQGHGVHHPQ-VSVSPRL------GTSRSSTVGN--GTLGY-ARPEA-----AA-A-A-SRGVHNAQRESVCTNL-------GTSESSTVGD--GTLGY-ARPAA-----AA---A-SCGVHDPH-DSVCTN----------XVSDKDGLPCP-G--------------WSFDRH-KVRCRCL ------PSVPSPTVEDSDVPKCH-QETSSSSCSSSS--RAYHHKFFHRHSPAVCSVL $-----Y D V H-P V I G-S P L T T C H-Q K G S R S S C S S S N-K T A Y H H K N D D Q H S P A E C S F L$ $-----Y D C A I P S L D D H-L F P N V-I E K A K L F L F I R N--T A Y H H K F V H H H S P A V C A V L$ $\star$
\end{abstract}

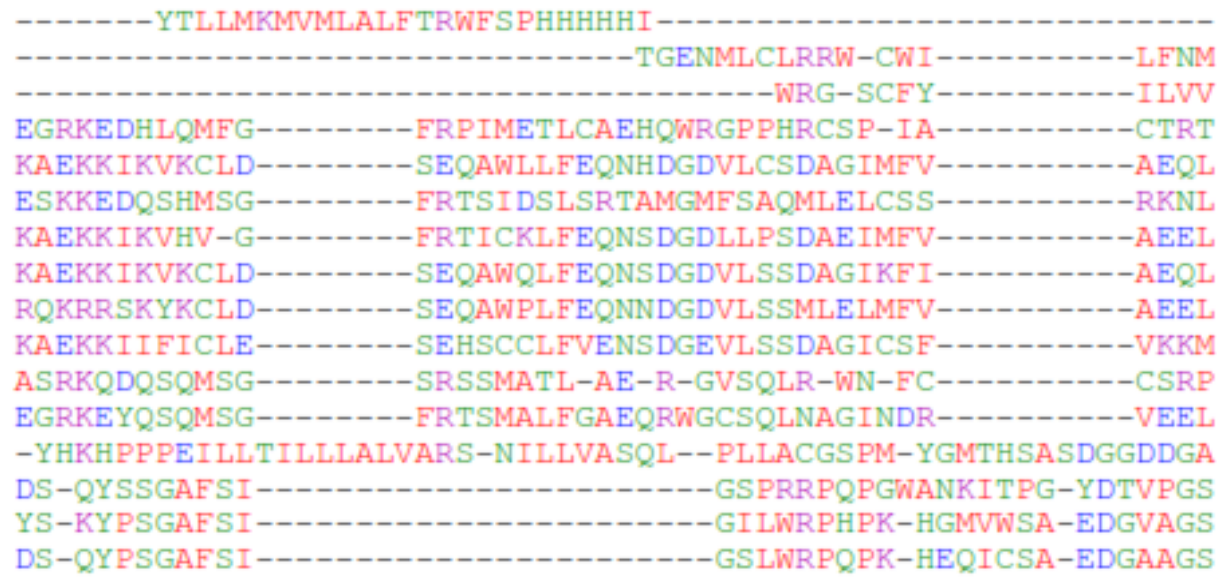

Multiple sequence alignment Result 
Fig.4 Neighbor joining tree based on CLUSTALW alignment of amino acid sequences of resistance gene candidate of Zingiber spp. collected from North-East India and NBS sequences of R-genes from other plant species. Bootstrap values are given at the nodes and the corresponding RGCs clustering together are indicated. Bootstrap values 1000 and the scale of genetic distance as computed from the pairwise distance in CLUSTALW are indicated. Four phylogenetic groups have been identified (A-D)

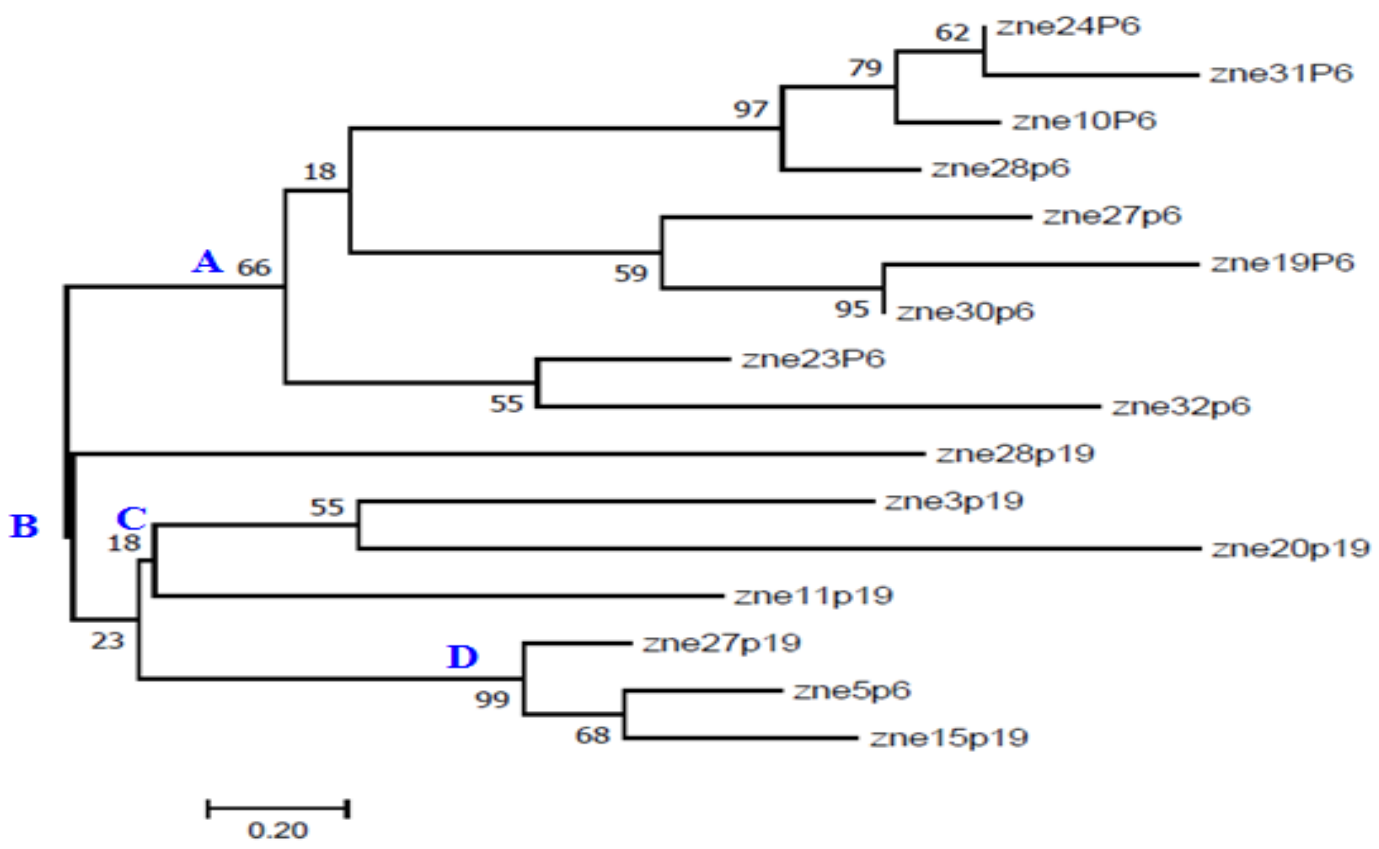

Fig.5 PCR amplification products of 300bp generated by the RGC specific primer pair designed 10p6; lane M- 100bp ladder; lane 4- Z. officinale makheer; lane 5- Z. zerumbet; lane 6- Z. zerumbet 126; lane 7- Z. sp 101; lane 8- Z. officinale maran; lane 9- Z. officinale MSa; lane 10Z. zerumbet var. Darceyi; lane 12- +ve Control

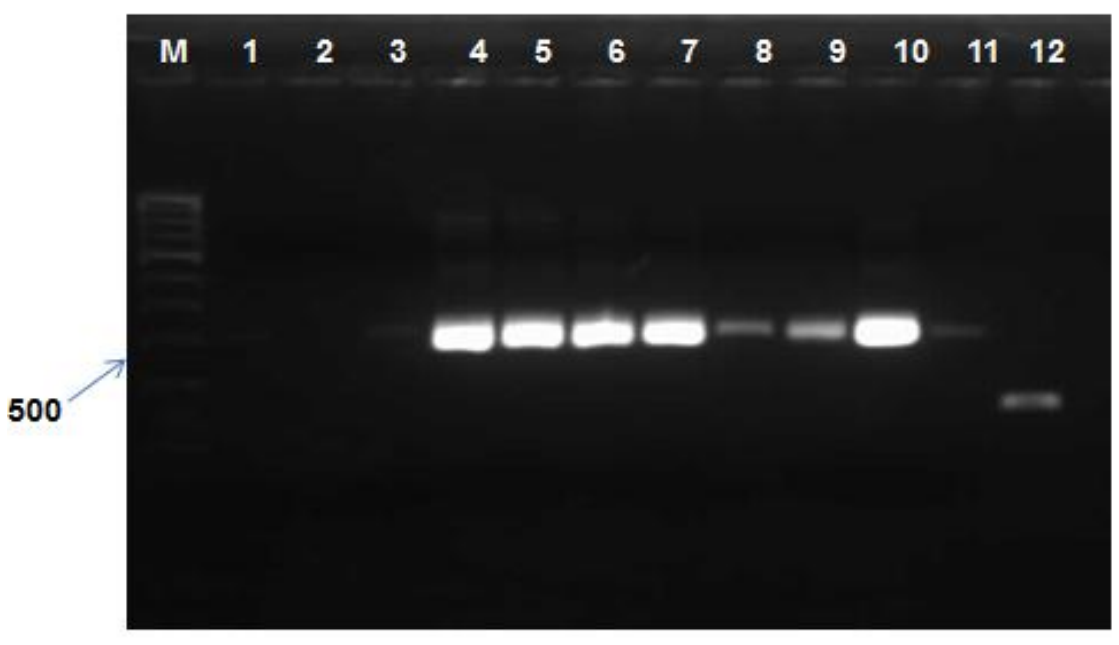


Fig.6 PCR Amplification products of 200bp generated by the RGC specific primer pair designed 23p6; lane1- Z. officinale var. Meitei shing; lane 2- Z. zerumbet; lane 3- Z. cassumnar 12; lane 4-

T6 Z. montanum; lane 6-. zerumbet var. Darceyi; lane 7- Z. sp 101; lane 8- Z. officinale bar ; lane10- Z. officinale ZRL; lane 12- Z. zerumbet 126; lane 13- Z. zerumbet var. Darceyi 40; lane 15- Z. officinale Hei ; ; lane 16- +ve control; lane M- 100bp ladder

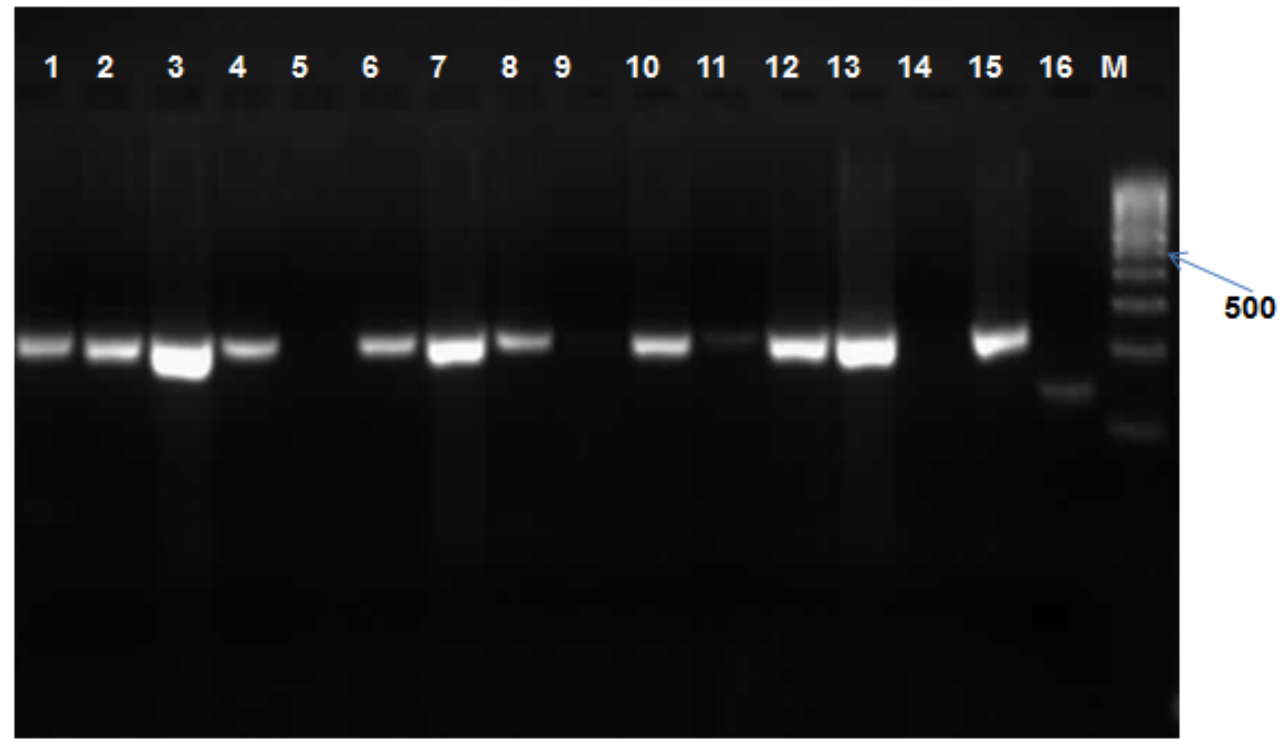

\section{Expression analysis}

Using the 10RGC specific primers designed to Zingiber RGCs, PCR was carried out with genomic DNA of the 14 accessions of Zingiber spp. in which PCR amplification product is detected with disease resistance degenerate primers. The 10 primers yielded PCR products of the predicted size from the DNA. When RT-PCR was conducted with the 10RGC specific primer pairs, only two primer pairs i.e., RSP1 and RSP3 were found to yield amplification products of $300 \mathrm{bp}$ and $200 \mathrm{bp}$ respectively (Fig. 6 and 7). These results show that the RGCs failed to produce a transcript for disease resistance. The lack of expression might be due to presence of some non-functional promoter preceeding the sequences or due to expression of low transcript levels were not expressed or the RGCs might correspond to pseudogenes. It has been reported earlier that majority of the NBS-LRR resistance genes are generally expressed at a low level (Hulbert et al., 2001).
Expression of R-genes has been found in highly resistant varieties but not in partially resistant varieties (Swetha et al., 2008). The amplicons were gel purified, cloned and sequenced at Bioserve technologies. The sequence data were used for homology searches. The RT-PCR products amplified were not related with disease related proteins and did not show any significant similarity with the R-genes of other plant species. They were uncharacterised proteins.

In summary, Fusarium resistance gene candidates from Zingiber spp. have not been isolated and characterised till now from the North-eastern region of India. This study aims at isolating and characterising the RGCs in the region for the first time. From the results we can conclude that Zingiber RGCs belong to the CC-NBS-LRR class of proteins and no TIR-RGCs were found in the study. Although RGCs were detected with degenerate RGC primers and the RGC-specific primers we designed. The expression of the disease 
resistance seems to be very low or absent in the Zingiber species found in the region.

\section{Acknowledgement}

The authors are thankful to the Director, Institute of Bio-resources and Sustainable Development, Department of Biotechnology (DBT), Govt. of India, Takyelpat, Imphal for providing financial support and research facilities.

\section{References}

Aarts MG, Hekkert B, Holub EB, Beynon JL, Stiekema WJ, Pereira A (1998). Identification of R-gene homologous DNA fragments genetically linked to disease resistance loci in Arabidopsis thaliana. Mol Plant Microbe Interact 11:251-258

Anderson P, Lawrence G, Morrish B, AyliVe M, Finnegan E, Ellis J (1997) Inactivation of the Xax rust resistance gene $\mathrm{M}$ associated with the loss of a repeated unit within the leucine-rich repeat coding region. Plant Cell 9:641651

Annonymous, (2002). Basic Statistics of North Eastern Region, North Eastern Council, Ministry of Home Affairs, Shillong

Bai J, Pennill L, Ning J, Lee S, Ramalingam J, Webb C, Zhao B, Sun Q, Nelson J, Leach J, Hulbert S (2002). Diversity in nucleotide binding site-leucine-rich repeat genes in cereals. Genome Res 12:1871-1884

Baker B, Zambryski P, Staskawicz B and Dinesh-Kumar S P 1997.Signaling in plant-microbe interactions. Science 276: 726-733

Baldi P, Patocchi A, Zini E, Toller C, Velasco $\mathrm{R}$ and Komjanc M (2004). Cloning and linkage mapping of resistance gene homologues in apple. Theoretical and
Applied Genetics. vol. 109, no. 1, p. 231-239

Belkhadir, Y., Nimchuk, Z., Hubert, D.A., Mackey, D., and Dangl, J.L. (2004). Arabidopsis RIN4 negatively regulates disease resistance mediated by RPS2 and RPM1 downstream or independent of the NDR1 signal modulator and is not required for the virulence functions of bacterial type III effectors AvrRpt2 or AvrRpm1. Plant Cell 16:2822-2835

Dangl JL, Jones DG (2001). Plant pathogens and integrated defence responses to infection. Nature 411:826-833

Deng Z, Gmitter FJ (2003). Cloning and characterization of receptor kinase class disease resistance gene candidates in Citrus. Theor Appl Genet 108:53-61

Deng Z, Huang S, Ling P, Chen C, Yu C, Weber C, Moore G, Gmiter FJ (2000). Cloning and characterization of NBSLRR class resistance- gene candidate sequences in citrus. Theor Appl Genet 101:814-822

Dixon MS, Hatzixanthis K, Jones DA, Harrison K, Jones JDG (1998). The tomato $\mathrm{Cf}-5$ disease resistance gene and six homologs show pronounced allelic variation in leucine-rich repeat copy number. Plant Cell 10:1915-1925

Dohroo, N.P. 1989. Seed transmission of preemergence rot and yellows in ginger. Plant Dis Res. 4:73-74

FAOSTAT (2010). Food and Agricultural commodities production. http://faostat. fao.org/site/339/default.aspx. Accessed 31 Aug 2010

FAOSTAT Citation database results (2005). Food and Agricultural Organization, Rome. http://faostat.fao.org Cited 01 July 2006

Ferrier-Cana E, GeVroy V, Macadre C, Creusot F, Imbert-Bollore P, Sevignac M, Langin T (2003). Characterization of expressed NBS-LRR resistance gene 
candidates from common bean. Theor Appl Genet 106:251-261

Feuillet C, Schachermayr G, Keller B (1997). Molecular cloning of a new receptorlike kinase gene encoded at the Lr10 disease resistance locus of wheat. Plant J 11:45-52

Flor H.H. (1956). The complementary genetic systems in flax and flax rust. Adv. Genet. 8: 29-54

Flor HH (1971). The current status of gene for gene concept. Ann Rev Phytopathol 9:275-296

Gassmann W, Hinsch ME and Staskawicz BJ (1999). The Arabidopsis RPS4 bacterial-resistance gene is a member of the TIR-NBS-LRR family of diseaseresistance genes. Plant J. 20: 265-277

Grant MR, Godiard L, Straube E, AshWeld T, Lewald J, Sattler A, Innes RW, Dangl JL (1995). Structure of the Arabidopsis RPM1 gene enabling dual specificity disease-resistance. Science 269:843846

H. Rahman, R. Karuppaiyan, K. Kishore and R. Denzongpa (2009). Traditional Practices of Ginger Cultivation in Northeast India. Indian Journal of Traditional Knowledge 8 (1): 23-28

Hammond-Kosack KE and Jones JD (1997). Plant disease resistance genes. Annu. Rev. Plant Physiol. Plant Mol. Biol. 48: 575-607

He CY, Tian AG, Zhang JS, Zhang ZY, Gai JY, Chen SY (2003). Isolation and characterization of a full-length resistance gene homolog from soybean. Theor Appl Genet 106:786-793

Hulbert, S. H., Webb, C. A., Smith, S. M., and Sun, Q. (2001). Resistance gene complexes: Evolution and utilisation. Annual Review of Phytopathology, 39, 285-312

Ilag L L, Yadav R C, Huang N, Ronald P C and Ausubel F M (2000). Isolation and characterization of disease resistance gene homologues from rice cultivar IR64.Gene, vol. 255, no. 2, p. 245-255

Irigoyen ML, Loarce Y, Fominaya A, Ferrer E (2004). Isolation and mapping of resistance gene analogues from the Avena strigosa genome. Theor Appl Genet 109:713-724

Johal G, Briggs S (1992). Reductase activity encoded by the HM1 disease resistance gene in maize. Science 258:985-987

Joshi RK, Kar B, Mohanty S, Subudhi E, Nayak S (2012). Molecular cloning, characterization, and expression analysis of resistance gene candidates in Kaempferia galangal L. MolBiotechnol 50:200-210.

Kanazin V, Marek LF, Shoemaker RC (1996). Resistance gene analogs are conserved and clustered in soybean. Proc Natl Acad Sci USA 93:11746-11750

Karlin.S. \& Altschul. S. F. (1990). Proc. Nat. Acad. Sci. USA. 87. 2264-2268

Kavitha P G and Thomas G (2007). Evaluation of Zingiberaceae for resistance to ginger soft rot caused by Pythium aphanidermatum (Edson) Fitzp. Plant Genet. Resorc. Newslett. $1521-4$

Lacock L, Van Niekkerk C, Loots S, Du Preez F and Botha A M (2003). Functional and comparative analysis of expressed sequences from Diuraphis noxia infested wheat obtained utilizing the conserved Nucleotide Binding Site. African Journal of Biotechnology, vol. 2, no. 4 , p. $75-81$

Lawrence BM (1984). Major tropical spices-ginger (Zingiber officinale Rosc.). Perfum Flavor 9:1-40

Leister D, Ballvora A, Salamini F, Gebhardt C (1996). A PCR-based approach for isolating pathogen resistance genes from potato with potential for wide application in plants. Nat Genet 14:421428 
Liu J-J, Ekramoddoullah AKM (2003). Isolation, genetic variation and expression of TIR-NBS-LRR resistance gene analogs from western white pine (Pinus monticola Dougl Ex D Don.). Mol Genet Genom 270:432-441

Mago R, Nair S, Mohan M (1999). Resistance gene analogues from rice: cloning, sequencing and mapping. Theor Appl Genet 99:50-57

Meyers B, Kozik A, Griego A, Kuang H, Michelmore R (2003). Genome wide analysis of NBS-LRR-encoding genes in Arabidopsis. Plant Cell 15:809-834

Meyers BC, Dickerman AW, Michelmore RW, Sivaramakrishnan S, Sobral BW Young ND (1999). Plant disease resistance genes encode members of an ancient and diverse protein family within the nucleotide-binding super family. Plant J 20:317-332

Nair RA and Thomas G (2007).Evaluation of resistance gene (R-gene) specific primer sets and characterization of resistance gene candidates in ginger (Zingiber officinale Rosc.).Curr. Sci. 93: 61-66

Pan Q, Wendel J, Fluhr R (2000). Divergent evolution of plant NBSLRR resistance gene homologues in dicot and cereal genomes. J Mol Evol 50:203-213

Purseglove J W, Brown E G, Green C L, Robbins S R J, (1981). Spices, vol. 1. Longman, London, New York, pp. 447531

Raabe R D, I L Conners and A P Martinez (1981). Checklist of plant diseases in Hawaii: including records of microorganisms, principally fungi, found in the state. Hawaii Institute of Tropical Agriculture and Human Resources (CTAHR), Information Text Series $022.313 \mathrm{pp}$.

Ravindran P N, Sasikumar B, Johnson K G, Ratnambal M J, Babu K N, Zachariah J T, Nair R R (1994). Genetic resources of ginger (Zingiber officinale Rosc.) and its conservation in India. Plant Genet Resour Newsl 98:1-4

Ravindran PN, Babu KN, Shiva KN (2005). Botany and crop improvement of ginger. In: Ravindran PN, Babu KN (eds) Monograph on ginger. CRC Press, Boca Raton pp 15-85

Rivkin MI, Vallejos CE, McClean PE (1999). Disease-resistance related sequences in common bean. Genome 42:41-47

Selvan MT, Thomas K G and Manojkumar K (2002). Ginger (Zingiber officinale Rosc.) in Indian spices: production and utilization (eds) H P Singh, K Sivaraman and $\mathrm{M} T$ Selvan (India: Coconut Development Board) pp 110131

Shen KA, Meyers BC, Nurul Islam Faridi M, Chin DB, Stelly DM, Michelmore RW (1998). Resistance gene candidates identified by PCR with degenerate oligonucleotide primers map to clusters of resistance genes in lettuce. Mol Plant Microbe Interact 11:815-823

Sheo, Govind, Chandra, Ram, Karibasappa G $\mathrm{S}$, Sharma $\mathrm{C} \mathrm{K}$ and Singh I P, (1998).Research on Spices in NEH Region. ICAR Research Complex for NEH Region, Umiam pp 9-22

Song WY, Pi LY, Wang GL, Gardner J, Holsten T, Ronald PC (1997). Evolution of the rice Xa21 disease resistance gene family. Plant Cell 9:1279-1287

Stirling A. 2004. The causes of poor establishment of ginger (Zingiber officinale) in Queensland, Australia. Australasian Plant Pathology 33:203-10

Swetha Priya, R., R. B. Subramanian (2007). Isolation and molecular analysis of $\mathrm{R}$ gene in resistant Zingiber officinale (ginger) varieties against Fusarium oxysporum f. sp. zingiberi. Bioresource Technology 99:4540-4543

Tang W, Eisenbrand G, (1992). Chinese Drugs of Plant Origin: Chemistry, Pharmacology, and Use in Traditional 
and Modern Medicine. Springer-Verlag, Berlin, New York, Pp. 1056.

Traut T W (1994). The functions and consensus motifs of nine types of peptide segments that form different types of nucleotide binding-sites. European Journal of Biochemistry. vol. 222, no. 1, p. 9-19

Whitham S, Dinesh-Kumar SP, Choi D, Hehl R, Corr C, Baker B (1994). The product of the tobacco mosaic virus resistance gene $\mathrm{N}$ : similarity to Toll and the interleukin-1 receptor. Cell 78:11011115

Xiao WK, Xu ML, Zhao JR, Wang FG, Li JS, Dai JR (2006). Genome wide isolation of resistance gene analogs in maize (Zea mays L.). Theor Appl Genet 113:63-72

Zhang J, Guo WZ, Zhang TZ (2002). Molecular linkage map of allotetraploid cotton (Gossypium hirsutium L $£$ Gossypium barbadense L) with a haploid population. Theor Appl Genet 105:1166-1174

Zhou T, Wang T, Chen JQ, Araki H, Jing Z, Jiang K, Shen J, Tian D (2004). Genome-wide identification of NBS genes in japonica rice reveals significant expansion of divergent nonTIR NBS-LRR genes. Mol Genet Genom 271: 402-415

\section{How to cite this article:}

Lenbi, N.C., Huidrom Sunitibala Devi and Pratap Jyoti Handique. 2018. Isolation and Characterisation of Fusarium Resistance Gene Candidates in Zingiber spp. of North East India. Int.J.Curr.Microbiol.App.Sci. 7(09): 430-443. doi: https://doi.org/10.20546/ijcmas.2018.709.053 